\title{
The first record of the spider subfamily Urocteinae Thorell, 1869 (Aranei: Oecobiidae) in Tajikistan
}

\author{
Urocteinae Thorell, 1869 (Aranei: Oecobiidae) - новое дмя \\ Таджикистана подсемейство пауков
}

\author{
Alexander A. Fomichev ${ }^{1}$, Yuri M. Marusik ${ }^{2,3}$ \\ А.А. Фомичев ${ }^{1}$, Ю.М. Марусик ${ }^{2,3}$
}

\footnotetext{
${ }^{1}$ Altai State University, Lenina Pr., 61, Barnaul, RF-656049, Russia. E-mail: a.fomichov@mail.ru

${ }^{1}$ Алтайский государственный университет, проспект Ленина, 61, Барнаул, 656049, Россия.

${ }^{2}$ Institute for Biological Problems of the North RAS, Portovaya Str.18, Magadan, Russia. E-mail: yurmar@mail.ru

${ }^{3}$ Department of Zoology \& Entomology, University of the Free State, Bloemfontein 9300, South Africa.

${ }^{2}$ Институт биологических проблем Севера ДВО РАН, Портовая, 18, Магадан, 685000, Россия.
}

KEY WORDS: Araneae, Central Asia, Hissar Mt. Range, new record.

КЛЮЧЕВЫЕ СЛОВА: Araneae, Центральная Азия, Гиссарский хребет, новая находка.

ABSTRACT: The female of a poorly known species, Uroctea grossa Roewer, 1960, is redescribed based on newly collected material from Tajikistan. The genus Uroctea Dufour, 1820 and the subfamily Urocteinae Thorell, 1869 are recorded from Tajikistan for the first time, and the new record represents the northeasternmost locality of the species' range. Digital photographs (including the first illustration of the vulva) and a map of distribution records of $U$. grossa are provided.

How to cite this article: Fomichev A.A., Marusik Yu.M. 2020. The first record of the spider subfamily Urocteinae Thorell, 1869 (Aranei: Oecobiidae) in Tajikistan // Arthropoda Selecta. Vol.29. No.2. P.235238. doi: 10.15298/arthsel. 29.2.08

РЕЗЮМЕ: На основании нового материала переописана самка плохо известного вида Uroctea grossa Roewer, 1960. Род Uroctea Dufour, 1820 и подсемейство Urocteinae Thorell, 1869 впервые отмечаются для Таджикистана. Новая находка является самой северо-восточной известной точкой ареала вида. Приводятся фотографии U. grossa (включая первую иллюстрацию вульвы) и карта находок вида.

\section{Introduction}

Oecobiidae Blackwall, 1862 is a relatively small spider family consisting of 119 species in six genera distributed almost worldwide [WSC, 2020]. Three genera are known from Central Asia: Ambika Lehtinen, 1967, Oecobius Lucas, 1846 (Oecobiinae) and Uroctea Dufour, 1820 (Urocteinae) [Mikhailov, 2013]. Uroctea is a single genus of the subfamily Urocteinae Thorell, 1869. Two species of Uroctea are known to occur in Central Asia: U. grossa Roewer, 1960 and U. limbata
(C.L. Koch, 1843) [WSC, 2020]. To date, Uroctea is known only in two Central Asian countries (former Soviet Union republics), Turkmenistan and Kazakhstan [Mikhailov, 2013]. While examining spider material collected in Tajikistan, we found a female belonging to $U$. grossa, a species known from females only and considered in only two taxonomic publications [Roewer, 1960; Zamani et al., 2015]. The goals of this paper are to report that this species and the subfamily Urocteinae that have been found in Tajikistan for the first time and to provide a detailed redescription of the female of $U$. grossa.

\section{Material and methods}

The specimen was photographed with a Canon EOS 7D camera attached to an Olympus SZX16 stereomicroscope at the Zoological Museum, University of Turku, Finland. Photographs were taken in a dish filled with alcohol, with cotton on the bottom. The epigyne was macerated in a $\mathrm{KOH} /$ water solution until the soft tissues were dissolved. Digital images were prepared using Helicon Focus software (https://www. photo-soft.ru/helicon-focus/). All measurements are in millimeters. Lengths of leg segments were measured on the dorsal side and are given as: total (femur, patella, tibia, metatarsus, tarsus). We followed the standard description and terminology used in Yang et al. [2019], with some changes. The material will be deposited in the Institute of Systematics and Ecology of Animals SB RAS, Novosibirsk, Russia (ISEA) and in the Zoological Museum, University of Turku, Finland (ZMUT).

Abbreviations

Collectors: AF — Alexander A. Fomichev, YM - Yuri M. Marusik.

Eyes: ALE - anterior lateral eye, AME - anterior median eye, MOA - median ocular area, MOA-L — length of MOA, MOA-WA - anterior width of MOA, MOA-WP posterior width of MOA, PLE - posterior lateral eye, PME posterior median eye. 

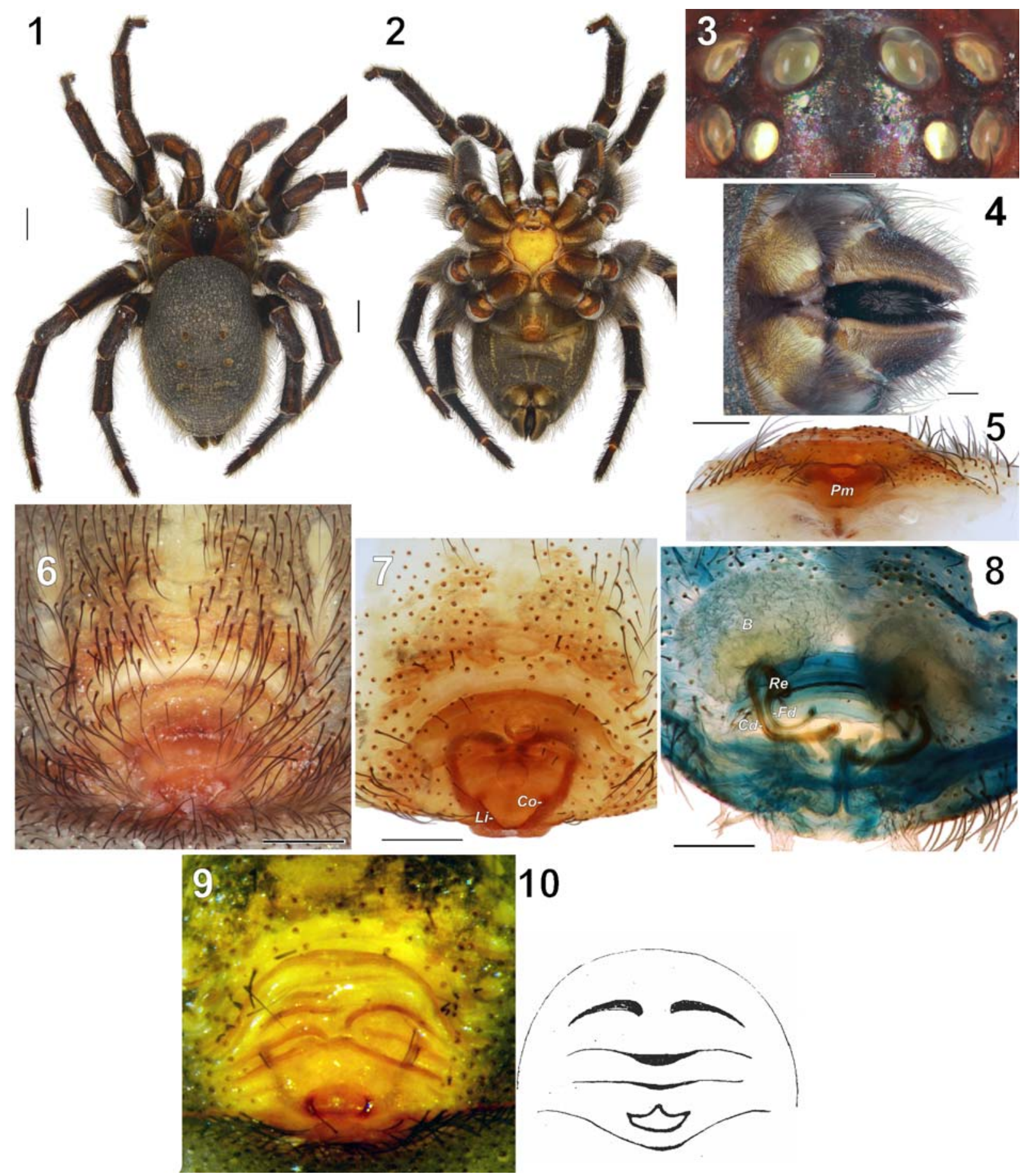

10

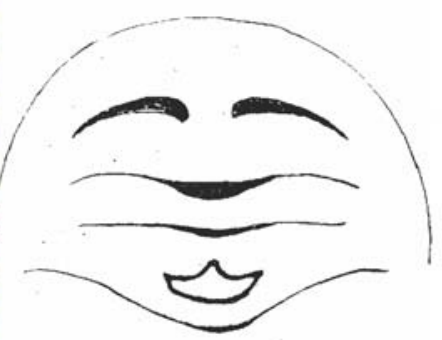

Figs 1-10. Female of Uroctea grossa from Tajikistan (1-8), Iran (9) and Afghanistan (10): habitus (1-2), eyes (3), spinnerets (4), intact (5-7, 9-10) and macerated (8) epigyne. 1, 3, 8 - dorsal; 2, 4, 6-7, 9-10 - ventral; 5 - posterior. 9 - after Zamani et al. [2015]; 10 - after Roewer [1960]. Scale bars: $1-2-2 \mathrm{~mm}, 3-0.2 \mathrm{~mm}, 4-8-0.5 \mathrm{~mm}$. Abbreviations: $\mathrm{Bu}$ - bursa, $\mathrm{Cd}$ - copulatory duct, $\mathrm{Co}-$ copulatory opening, $\mathrm{Fd}$ - fertilization duct, $L i$ - lip of epigyne, $P m$ - posterior epigynal margin, Re - receptacle.

Рис. 1-10. Самка Uroctea grossa из Таджикистана (1-8), из Ирана (9) и из Афганистана (10): внешний вид (1-2), глаза (3), паутинные бородавки (4), интактная $(5-7,9-10)$ и мацерированная (8) эпигина. $1,3,8$ - дорзально; 2, 4, 6-7, 9-10 - вентрально; 5 - сзади. 9 - по Zamani et al. [2015]; 10 - по Roewer [1960]. Масштабные линейки: 1-2 - 2 мм, 3 - 0,2 мм, 4-8 - 0,5 мм. Сокращения: $B u$ - бурса, $C d$ - копулятивный проток, $C o-$ копулятивное отверстие, $F d-$ оплодотворительный проток, $L i-$ губа эпигины, $P m-$ задний край эпигины, $R e-$ рецептакула. 


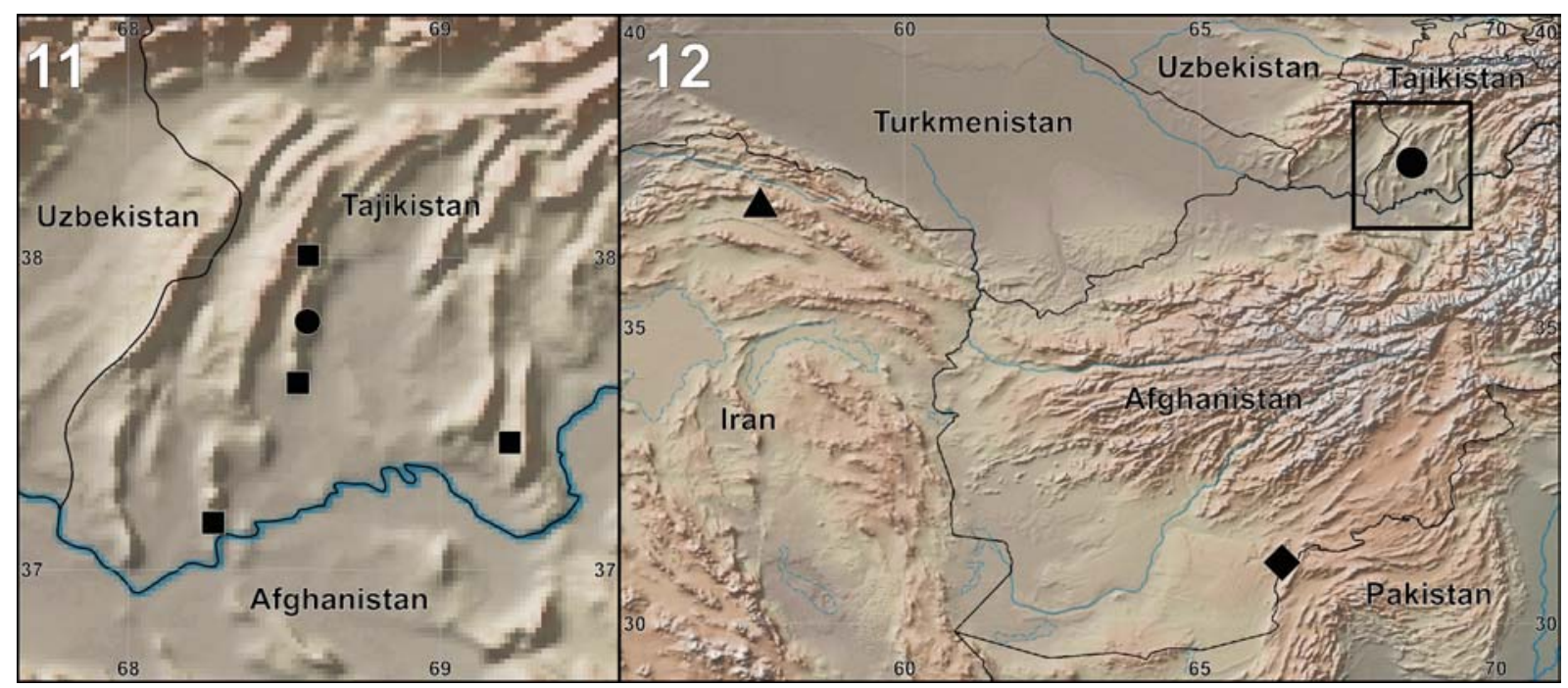

Figs 11-12. Distribution records of Uroctea grossa. Type locality — diamond; record from Iran — triangle; new record from Tajikistan — circle; juvenile specimens from Tajikistan - square. Frame on Fig. 12 refers to Fig. 11.

Рис. 11-12. Точки находок Uroctea grossa. Типовая местность — ромб; находка в Иране — треугольник; новая находка в Таджикистане - кружок; ювенильные особи из Таджикистана - квадрат. Рамка на рис. 12 соответствует рис. 11.

\section{Redescription}

\section{Uroctea grossa Roewer, 1960}

Figs $1-12$.

U. grossa Roewer, 1960: 51, f. 18a-d (+).

U. grossa: Zamani et al., 2015: 342, f. 4a-d (+).

MATERIAL EXAMINED. TAJIKISTAN: Khatlon Region: 9 (ISEA) Aruktau Mt. Range, $7 \mathrm{~km}$ SW from Sambuli Village, $37^{\circ} 45.602^{\prime} \mathrm{N}, 68^{\circ} 32.741^{\prime} \mathrm{E}$, dry stony shiblyak shrubland with rocks, 660-980 m, 9.04.2019, AF; 1 juv. (ISEA) Aruktau Mt. Range, 6 $\mathrm{km}$ ENE from Garavuti Village, $37^{\circ} 35.389^{\prime} \mathrm{N}, 68^{\circ} 31.654^{\prime} \mathrm{E}$, stony desert, 400-630 m, 7-8.04.2019, AF; 2 juv. (ISEA) Ichkoran Mt. Range, $2 \mathrm{~km}$ E from Teshiktosh Village, $37^{\circ} 08.310^{\prime} \mathrm{N}, 68^{\circ} 15.462^{\prime} \mathrm{E}$, stony desert with rocks, 600-760 m, 6.04.2019, AF; 1 juv. (ZMUT)

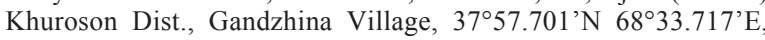
cliff, dry slopes, under stones, $716 \mathrm{~m}, 21.04 .2015$, YM; 2 juv. (ZMUT) foothills of Astana Mt., 37²2.919’ N, 69² $12.540^{\prime} \mathrm{E}$, canyon stony-clay, $870 \mathrm{~m}, 4.05 .2015$, YM.

DIAGNOSIS. This species differs from all other Uroctea, with the exception of $U$. thaleri Rheims, Santos et van Harten, 2007, by the wrinkled epigyne and uniformly-colored, dark abdomen lacking a pattern. Uroctea grossa can be distinguished from $U$. thaleri by the diverging distal parts of the copulatory ducts ( $v s$. converging) (cf. Fig. 8 and fig. 8 in Rheims et al. [2007]).

DESCRIPTION. Female. Total length 14.5. Carapace: 5.7 long, 7.0 wide. Abdomen: 11.3 long, 8.0 wide. Eye measurements: AME 0.33, ALE 0.29, PME 0.2, PLE 0.27; AME-AME 0.26, AME-ALE 0.06, ALE-PLE 0.09, PMEPLE 0.03, PME-PME 0.64; MOA-L 0.64, MOA-WA 0.81, MOA-WP 0.99. Coloration. Carapace brown, with longitudinal dark brown median stripe and dirty-yellow edges. Sternum bright yellow. Labium yellow anteriorly, dark brown posteriorly. Maxillae yellow-brown. Chelicerae dark brown. Coxae brown with yellow spots. Palps and legs dark brown with longitudinal yellow-brown stripes. Abdomen gray with small dirty-yellow speckles. Spinnerets yellow-gray (Figs 1-2). Leg measurements: I 19.15 (5.8, 3.0, 3.65, 4.35, 2.35); II $19.65(5.95,3.1,3.7,4.65,2.25)$; III $20.35(6.15,3.15$,
3.6, 5.25, 2.2); IV $21.15(6.5,3.6,3.4,5.35,2.3)$. Epigyne as in Figs 5-10. The posterior epigynal margin $(P m)$ with a small triangular notch. Copulatory openings $(\mathrm{Co})$ small and barely visible, located on the posterior part of the epigyne. Copulatory ducts $(C d)$ thin and long, forming an obtuse angle. Receptacles $(R e)$ elongated, widely spaced. Fertilization ducts $(F d)$ thin and long. All parts of the endogyne asymmetric.

Male unknown

DISTRIBUTION. The species is known from northeastern Iran and from southern Afghanistan [Roewer, 1960; Zamani et al., 2015]. The new record from southwestern Tajikistan represents the northeasternmost locality of the species. The record of $U$. limbata from the Kyzylkum Desert [Logunov et al., 2012] may refer to U. grossa. Uroctea limbata has an abdominal pattern, but the figure of the female provided in Logunov et al [2012] has no abdominal pattern, as in the species re-described here. The same may be true for the records of $U$. limbata from Turkmenistan (see Simon [1899] and consequent authors).

\section{Discussion}

The genus Uroctea and the subfamily Urocteinae were found in Tajikistan for the first time. In addition to the adult female, we collected several juvenile Uroctea specimens that we assume to be $U$. grossa from four other localities. All collections in Tajikistan are from the southern part of the Hissar Mt. Range (Fig. 11). It is likely that this species is widespread in Asia and occurs also in Pakistan, Turkmenistan, Uzbekistan and Kazakhstan (Fig. 12).

Acknowledgements. We thank V.O. Shablya (Moscow, Russia) for organizing an expedition to Tajikistan in which the material treated here was collected. Thanks go to S. Koponen and I. Sääksjärvi (Zoological Museum, University of Turku, Finland) for providing museum facilities. An ear- 
lier draft of the manuscript was reviewed by A. Zamani (University of Turku, Finland). The English of the final draft was kindly checked by Sarah Crews (San Francisco, USA).

\section{References}

Logunov D.V., Gromov A.V., Timokhanov V.A. 2012. Spiders of Kazakhstan. Manchester, UK: Siri Scientific Press. 232 pp.

Mikhailov K.G. 2013. The spiders (Arachnida: Aranei) of Russia and adjacent countries: a non-annotated checklist. Arthropoda Selecta. Supplement No.3. 262 pp.

Rheims C.A., Santos A.J., van Harten A. 2007. The spider genus Uroctea Dufour, 1820 (Araneae: Oecobiidae) in Yemen // Zootaxa. Vol.1406. P.61-68.

Roewer C.F. 1960. Solifugen und Opilioniden - Araneae Orthognathae, Haplogynae und Entelegynae (Contribution à l'étude de la faune d'Afghanistan 23) // Göteborgs Kungliga Veten- skaps och Vitterhets Samhälles Handlingar. Vol.8. No.7. P.153.

Simon E. 1899. Araneae Transcaspicae // G.I. Radde. Kollektsyi Kavkazskogo Museya (Museum Caucasicum). Vol.1. Zoologiya. Tiflis. P. $478-480$.

World Spider Catalog. 2020. World Spider Catalog. Version 21.0. Natural History Museum Bern, online at http://wsc.nmbe.ch (accessed on April 2020).

Yang Z.Z., Yang Z.B., Zhao Y., Zhang Z.S. 2019. Review of the tent-web spider genus Uroctea Dufour, 1820 in China, with descriptions of two new species (Araneae: Oecobiidae). Zootaxa. Vol.4679. No.1. P.126-138.

Zamani A., Mirshamsi O., Jannesar B., Marusik Y.M., Esyunin S.L. 2015. New data on spider fauna of Iran (Arachnida: Araneae), Part II // Zoology and Ecology. Vol.25. No.4. P.339346.

Responsible editor K.G. Mikhailov 